Wright State University

CORE Scholar

History Faculty Publications

History

1983

\title{
The Rural Ideal and Agrarian Realities: Arthur E. Holt, and the Vision of a Decentralized America in the Interwar Years
}

Jacob H. Dorn

Wright State University - Main Campus, jacob.dorn@wright.edu

Follow this and additional works at: https://corescholar.libraries.wright.edu/history

Part of the History Commons

\section{Repository Citation}

Dorn, J. H. (1983). The Rural Ideal and Agrarian Realities: Arthur E. Holt, and the Vision of a Decentralized America in the Interwar Years. Church History, 52 (1), 50-65.

https://corescholar.libraries.wright.edu/history/1

This Article is brought to you for free and open access by the History at CORE Scholar. It has been accepted for inclusion in History Faculty Publications by an authorized administrator of CORE Scholar. For more information, please contact library-corescholar@wright.edu. 


\title{
The Rural Ideal and Agrarian Realities: Arthur E. Holt and the Vision of a Decentralized America in the Interwar Years
}

\author{
JACOB H. DORN
}

A revolution in rural life since the 1940s has produced agribusiness, corporate farms, and a situation in which less than five percent of Americans are engaged in farming activities and fewer still work family farms. Richard Hofstadter once observed, "The United States was born in the country and has moved to the city." Today, when few vestiges remain of "the localistic and personalistic frame of reference, which describes farming and country life effectively all the way through the depression years," it is important to remember the influence that an idealized picture of rural life had on earlier generations of American intellectuals. Amidst the profound changes in American society produced by industrialization, urbanization, and corporate capitalism, many thinkers adhered to a vision of simpler times-one of grass-roots democracy and disinterested citizenship, of interpersonal intimacy and cooperation in a matrix of face-to-face relationships and of local control. Whether endeavoring to resuscitate this way of life or merely lamenting its passing, they displayed a reluctance to accept the new order in either city or countryside. ${ }^{1}$

Of course, the economic and demographic processes that would alter life on farms and in villages and small towns beyond recognition began before the 1940s. Rural depopulation became severe in some areas by the 1880 s, and after the turn of the century the rural exodus and decay of many rural churches and other institutions caused President Theodore Roosevelt to establish a Country Life Commission. Though the economic position of agriculture improved after the depression of the 1890s and remained strong

1. Richard Hofstadter, The Age of Reform: From Bryan to F.D.R. (New York, 1955), p. 23. John L. Shover, First Majority-Last Minority: The Transforming of Rural Life in America (DeKalb, Ill., 1976), p. xvi; Shover's book is a poignant analysis of the revolution in rural life since the 1940s. Jean Quandt, From the Small Town to the Great Community: The Social Thought of Progressive Intellectuals (New Brunswick, N.J., 1970), examines the nostalgia for simpler times in the thought of nine people, including John Dewey, Charles $\mathrm{H}$. Cooley, Jane Addams, Josiah Royce, and Robert E. Park, who identified personally and professionally with urban life. Morton White and Lucia White, The Intellectual Versus the City: From Thomas Jefferson to Frank Lloyd Wright (Cambridge, Mass., 1962) offer a comprehensive interpretation of antiurban thought.

Mr. Dorn is professor of history in Wright State University, Dayton, Ohio. 
until the end of the First World War, alarm over threats to the quality of rural life led in the Progressive era to many studies and organizations whose purpose was to make rural life attractive again and thereby to reinvigorate this source of American values. ${ }^{2}$

Since churches were a mainstay of rural life, religious leaders naturally figured prominently in these efforts. For example, the needs of rural churches gave focus to the developing ecumenical movement in Ohio, and at the national level the young Federal Council of Churches established a Commission on the Church and Country Life in 1913 and published field studies of rural churches in Ohio and elsewhere. ${ }^{3}$ From the creation of the Presbyterian Department of the Church and Country Life in 1910 through the 1920s and 1930s, the Protestant denominations established various bureaus and fellowships to strengthen rural churches and their communities. The creation in 1923 of the National Catholic Rural Life Conference indicates a parallel interest outside of Protestantism. ${ }^{4}$

Scholars have given more attention to the formative years of the rural life movement than to the period between the two world wars. ${ }^{5}$ The interwar years were a time of turmoil and dislocation in rural America. A wartime boom collapsed in 1920 because of the removal of governmental price supports and the constriction of foreign demand. Tenancy increased throughout the 1920s, and farmers operated at a net loss for most years in that decade. The flow of people to cities continued apace. Beyond encouraging cooperative marketing and increased exports, the Republican administrations of those years did little to ease the plight of farmers. The Great Depression only worsened matters, and by 1932 farmers, who accounted for about 25 percent of the population, received only about 5 percent of the total national income. Before the New Deal's farm programs began to improve conditions, there were milk strikes, mortgage foreclosures were turned into "penny auctions," dust storms in the Southwest produced mass migrations of "Okies" and "Arkies," and other signs indicated truly desperate straits in America's heartland. Even the New Deal did not alleviate all rural distress. New Deal programs aided primarily the better organized landowning farmers, and, in

2. William L. Bowers, The Country Life Movement in America, 1900-1920 (Port Washington, N.Y., 1974); Merwin Swanson, "The 'Country Life Movement' and the American Churches," Church History 45 (September 1977): 358-373.

3. See Jacob H. Dorn, Washington Gladden: Prophet of the Social Gospel (Columbus, 1967), pp. 370-377. The Gifford Pinchot Collection at the Library of Congress, containers 1740-1741 and 2070-2071, richly documents the Federal Council's efforts; Pinchot chaired its commission.

4. Mark Rich, The Rural Church Movement (Columbia, Mo., 1957).

5. Merwin Swanson, whose dissertation does extend to 1940, suggests that denominational agencies became more concerned with strengthening their own churches than with community development and that the original movement faltered after the First World War ("The 'Country Life Movement,"” p. 373; see also "The American Country Life Movement, 1900-1940" [Ph.D. diss., University of Minnesota, 1972]). 
fact, crop reduction mechanisms drove thousands of sharecroppers off lands they had worked. ${ }^{6}$

It would require much research to reconstruct and interpret the Protestant rural life movement in these decades of economic disaster. Two leading studies of Protestant thought on social and political issues during these years-Robert M. Miller's American Protestantism and Social Issues, 19191939 and Donald B. Meyer's The Protestant Search for Political Realism, 1919-1941-have emphasized many issues other than the welfare of agriculture and the quality of rural life. ${ }^{7}$ Because the industrial crisis of the 1930s seemed to demand precedence over everything else, emphasis on the churches' engagement with unemployment, labor organization, and industrial planning is understandable. But rural life had been a part of the Social Gospel's agenda before the war, and, though interest may have slackened, that tradition continued to include the welfare of farm and village in its understanding of social justice.

Among other developments, a number of religious bodies broadened their social statements, which in the Progressive era had consisted of urban and industrial goals, to include agriculture. In their "Statement of Social Ideals" in 1925, Congregationalists became the first to "call attention directly to rural America." Later endorsed by the Reformed and northern Methodist denominations, this statement identified land security, lower distribution costs, better social, cultural, and recreational opportunities, and cooperative organization as the major needs of rural Americans. Similarly, when in 1932 the Federal Council revised its "Social Creed" of 1912, it rectified the earlier neglect of rural issues by devoting two sections to economic justice for farmers and to the enhancement of rural social and cultural life and by relating rural to urban-industrial concerns in three others. When in 1934 Congregationalists elevated the status of their social service commission to that of a major independent agency, the new Council for Social Action had four divisions, with rural life taking its place alongside units on industrial, racial, and international relations. ${ }^{8}$

6. Gilbert C. Fite, "The Farmers' Dilemma, 1919-1929," in John Braeman et al., Change and Continuity in Twentieth-Century America: The 1920s (Columbus, 1968), pp. 67-102; Theodore Saloutos and John D. Hicks, Agricultural Discontent in the Middle West, 1900-1939 (Madison, 1951); John L. Shover, Cornbelt Rebellion: The Farmers' Holiday Association (Urbana, Ill., 1965); and Theodore Saloutos, "New Deal Agricultural Policy: An Evaluation," Journal of American History 61 (September 1974): 394-416.

7. Robert M. Miller, American Protestantism and Social Issues, 1919-1939 (Chapel Hill, 1958); Donald B. Meyer, The Protestant Search for Political Realism, 1919-1941 (Berkeley, 1960).

8. F. Ernest Johnson, ed., The Social Work of the Churches: A Handbook of Information (New York, 1930), p. 124; "A Statement of Social Ideals," Social Action 8 (15 May 1942): 41-42; F. Ernest Johnson, "After Thirty Years: A National Inventory in Terms of the Social Ideals of the Churches," Information Service (20 June 1942): 8-9; Miller, American Protestantism and Social Issues, pp. 79-81, 235-237; Alfred W. Swan, "Father of the Council for Social Action," Chicago Theological Seminary Register 32 (March 1942): 20-22. 
A central figure in many of liberal Protestantism's gestures to attain justice for rural people was Arthur E. Holt, professor of social ethics in Chicago Theological Seminary from 1924 until his death in 1942, with a joint appointment at the University of Chicago Divinity School. Holt was active both in secular organizations, such as the Committee on Rural Life of the National Conference of Social Work and the American Country Life Association, and in denominational and ecumenical rural programs. He wrote widely on rural subjects for producers' publications, rural life journals, and the religious press. ${ }^{9}$ His conceptualization of the issues was widely influential, and thus an examination of his career and his thought is instructive. Such an examination reveals that while urban liberal Protestant thinkers achieved admirable prophetic insight into the rural plight, that insight was sometimes blurred by a confusion between immediate social and economic problems and a nostalgic ruralist ideology. It also reveals an inability to formulate a program of action that might succeed in resisting the erosion of the decentralized America that men like Holt idealized.

Born in Longmont, Colorado, in 1876, Holt grew up in a family for which the Presbyterian church and the struggle to make a living off of semiarid land were central. His father, Asa D. Holt, had joined the first Grange in the United States in his native Fredonia, New York, and had migrated to Colorado in 1871 as a member of the Horace Greeley colony. He helped to organize cooperative irrigation, milling, and elevator companies in Longmont and worked to shape the state's laws to establish use rights for its rivers and streams. The community in which Arthur Holt grew up, along with his father's public-spiritedness and commitment to cooperation, shaped to a considerable extent his understanding of rural life. ${ }^{10}$

After graduating from Colorado College, Holt entered the Yale Divinity School in 1898, but, finding Yale "stuffy" (and perhaps not democratic enough for his western tastes), he transferred to the Divinity School at Chicago after one year. The intellectual atmosphere there was exciting, and, as the first Ph.D. candidate of Gerald Birney Smith, Holt completed his work in 1904 with a dissertation on "The Function of Christian Ethics."

9. C. Howard Hopkins, pioneering historian of the Social Gospel, ranked him with Washington Gladden, Josiah Strong, and Graham Taylor as "the creative leaders" in Congregationalist social ministry ("A History of Congregational Social Action," Social Action 8 [15 May 1942]: 39). For biographical material, see Carlus O. Basinger, "Arthur E. Holt: The Man and His Social Ethics" (M.A. thesis, University of Chicago Divinity School, 1945); Arthur C. McGiffert, Jr., No Ivory Tower: The Story of the Chicago Theological Seminary (Chicago, 1965), pp. 186-198; and Jacob H. Dorn, "Arthur E. Holt," in Dictionary of American Biography: Supplement Three, 1941-1945, ed. Edward T. James (New York, 1973), pp. 362-364.

10. Basinger, "Holt," pp. 5-9; Arthur E. Holt, "A National Resource without a Scandal: What Has Been Done in Irrigation," Congregationalist 109 (22 May 1924): 648-650; Holt to John B. Holt, 18 November 1935, Holt Papers, Chicago Theological Seminary, Chicago, Ill.

11. Basinger, "Holt," pp. 9-26. 
1904 to 1919 he served three churches as pastor: First Congregational, Pueblo, Colorado, 1904-1909; First Congregational, Manhattan, Kansas, 1909-1916; and First Presbyterian, Fort Worth, Texas, 1916-1919. Records are scanty, but in each place Holt undertook in the manner of the Social Gospel to identify local needs that merited the church's attention. Of special importance, the pastorate in Manhattan's "town and gown" congregation enabled him to bring church and university people together to address problems of the surrounding countryside. ${ }^{12}$ Leaving the parish ministry permanently in 1919, Holt moved to Boston to become secretary of the Social Service Commission of the Congregational Education Society. Maintaining the commission's established urban-industrial focus, he worked closely with the Federal Council's Social Service Commission in planning industrial conferences and coauthored with F. Ernest Johnson Christian Ideals in Industry. ${ }^{13} \mathrm{He}$ also emphasized rural problems, devoting his office's entire report for 1923 to them. ${ }^{14}$

In 1924 Holt succeeded Graham Taylor as professor of social ethics in Chicago Theological Seminary (CTS). He was already an established figure within the social action agencies of his denomination and the Federal Council and would continue to be one, earning, for example, a reputation as "father" of the Council for Social Action. He now became influential in theological education through reforms carried out at CTS, largely under his leadership. Flush with a generous bequest from Victor Lawson, publisher of the Chicago Daily News, CTS put itself at the cutting edge of seminary curricular reform, with an emphasis on developing Holt's field, social ethics. Holt's strategic position was buttressed by the fact that Lawson also left substantial sums to the Chicago Congregational Missionary and Extension Society, with the specification that CTS's social ethics department function as its research arm. Arthur C. McGiffert, Jr., Holt's colleague as professor and then president, later observed: "Holt became, in effect, the unofficial academic leader of the Faculty. The educational emphasis of the Seminary in the 1930's reflected his own educational philosophy and emphases." 15

Whereas the principal interests in Taylor's era had been urban and industrial, Holt highlighted rural concerns. He recruited a cadre of men who shared his views and enlarged his influence through their own disparate careers: Carl R. Hutchinson, Anton T. Boisen, Samuel C. Kincheloe, and Shirley E. Greene were especially important. He also led the faculty to focus on training ministers for midwestern town and country parishes. In launch-

12. Charles M. Correll, The Manhattan Congregational Church, 1856-1956: A History (n.p., n.d.), pp. 27-29.

13. Arthur E. Holt and F. Ernest Johnson, Christian Ideals in Industry (New York, 1924).

14. "Dr. Holt and His Work," Congregationalist 109 (22 May 1924): 648. There are no primary records of the Congregational commission for Holt's secretaryship.

15. Ozora S. Davis, "The Chicago Theological Seminary: Report of the President to the Twenty-Fourth Triennial Convention ... September 23, 1924 to June 3, 1928," Holt Papers; McGiffert, No Ivory Tower, pp. 183-185, 196. 
ing a new program envisioned to include courses in rural arts, field experience in rural parishes, recruitment at agricultural colleges, and cooperation with the University of Chicago to develop the discipline of rural sociology, the faculty affirmed that the most pressing issue for American democracy was not the struggle between labor and management but rather, "whether we are to build our cities with a standard of life which cannot be matched on the farms." 16

Holt's move to Chicago also brought him into the orbit of the Christian Century, the nation's premier liberal Protestant magazine: from the late 1920 s until his death, no one wrote more of its pieces on agriculture. He also exerted influence on editorial positions through his friendship with managing editor Paul Hutchinson, with whom he worked in several Chicago organizations, including the local chapter of the League for Industrial Democracy. In a feature editorial on him in 1942, the Century noted that Holt regularly visited the editorial offices to chat about his plans and ideas and to make suggestions. ${ }^{17}$

In these important interwar years, then, Holt achieved recognition as an authoritative interpreter of rural life for liberal Protestantism. He was a logical figure to ask to write or speak about rural churches, farm policies, and related topics, and his papers indicate that he did so frequently for a wide variety of audiences. Much of his credibility rested on his pioneering use of social scientific research methods and his resultant reputation for having up-to-date, reliable data. In this regard, he typified many Protestants' hopeful embrace of social research in the early decades of the century. In the Progressive era muckrakers, social workers, and reformist clergy and educators had plunged into urban communities to gain a realistic view of social needs through case studies, neighborhood surveys, and similar techniques. The early rural life movement had applied such empirical methods to rural communities, as, for example, in studies by Gifford Pinchot and Charles O. Gill. The enthusiasm for social research as a basis for social policy continued in the years after the First World War. It marked Holt's career, as it did the activities of H. Paul Douglass's Institute of Social and Religious Research, with its urban church surveys and Douglass's own famous 1,000 City Churches. ${ }^{18}$

16. Samuel C. Kincheloe to author, 3 December 1980; Carl R. Hutchinson to author, 13 December 1980; Shirley E. Greene to author, 19 December 1980; Holt, "Town and Country Churches," CTS Register 17 (March 1927): 8-11; and Carl R. Hutchinson, "The Seminary Co-operates with Country Churches," ibid. 20 (January 1930): 11-14.

17. "Arthur Holt-A Modern Christian Pioneer," Christian Century 59 (21 January 1942): 67-68.

18. Charles O. Gill and Gifford Pinchot, The Country Church: The Decline of Its Influence and the Remedy (New York, 1913); idem, Six Thousand Country Churches (New York, 1919); H. Paul Douglass, 1,000 City Churches (New York, 1926). See also Douglass's The St. Louis Church Survey (New York, 1924) and The Springfield Church Survey (New York, 1926), and Benjamin E. Mays and Joseph W. Nicholson, The Negro's Church (New York, 1933). 
Holt brought this faith in social science to his work at CTS. Believing that the seminary should train ministers "to think accurately about their own social experience," he sought to provide the tools for understanding social changes that touched the lives of individuals and the fortunes of churches and their communities. Certain that surveys, interviews, and the case method could turn "the average parish, led by the average pastor," into a laboratory for seminaries and denominations, providing a continuous flow of information about group and individual experience, he enjoined his students to "Keep your facts ahead of your oratory!" His courses were noted for the use of maps, graphs, and charts-the equivalent, for him, of biblical scholars' primary documents. ${ }^{19}$

Three major projects conducted in the late 1920s for the Chicago Congregational Union and the Chicago Church Federation exemplified the belief that scientific investigation could give direction to social ethics. A study of hobos on West Madison Street began with the question "What happens when a mission stiff gets converted?" and ended with comprehensive suggestions for meeting the social, economic, and religious needs of transient laborers, many of them from rural areas. An investigation of the social make-up of 96 churches in Chicago provided useful conclusions for the church federation. Most importantly for Holt's interest in urban-rural conflict, a study of 200 dairy farmers in McHenry County, following enforcement in 1926 of Chicago's ordinance requiring tuberculin testing of dairy herds in the city's "milk shed," led to efforts to marshall religious support for higher prices for milk producers. ${ }^{20}$

Another effort to bring the seminary into firsthand contact with real life experience, especially rural experience, was the "Spring Hike." Each year from 1927 until his death, Holt led students and colleagues to some area

19. Holt's views on theological education and social experience were set forth in "How Can the Minister Co-operate With the Social Worker?" Proceedings of the National Conference of Social Welfare (1923): 249-252; "Observing the Vocational Experience of Your Parish," CTS Register 16 (March 1926): 3-8; "Trends in Theological Education," ibid. 19 (January 1929): 27-32; "Case Records as Data for Studying the Conditioning of Religious Experience by Social Factors," American Journal of Sociology 32 (September 1926): 227-236; "The Ecological Approach to the Church," ibid. 33 (July 1927): 72-79; "The Contribution of Sociology to the Making of the Minister," Crozer Quarterly 3 (October 1926): 432-439; "Case Method and Teaching at Chicago Theological Seminary," Religious Education 23 (March 1928): 207-212; "Legitimate Fields for Research," ibid. 23 (April 1928): 357-361; and (with Edwin D. Starbuck) "Theological Seminaries and Research," ibid. 23 (May 1928): 404-406.

20. Arthur E. Holt, "Personal Work with the Hobos," CTS Register 16 (March 1926): 10-12; idem, " "Bos," Survey Graphic 60 (1 August 1928): 456-459; idem, "Have the Laboring Men Deserted the Churches?" Federal Council Bulletin 10 (January 1927): 15; idem, "New Studies of the City Church," Christian Century 45 (27 September 1928): 1152; idem (with Carl R. Hutchinson), "The Religion of Two Hundred Farmers of McHenry County," 10 May 1928, Holt Papers; idem, "Pure Milk Members Go to Church according to Seminary Survey," Pure Milk 2 (June 1928): 3; idem, "A Study of Rural-Urban Conflict," Federal Council Bulletin 10 (May 1927): 11. 
where there was opportunity, as McGiffert remembered, "to seek out points of social significance, to learn at firsthand from the participants, at their level of knowledge, the facts and nature of their problem; to try to define possible lines of solution in the light of Christian ethics." Beginning with an actual walk through the "milk shed," where his entourage interviewed farmers, attended meetings, and put on programs in churches, Holt later used automobiles to reach more distant sites: Louisiana (to see "what lay back of the Huey Long movement"), the Tennessee Valley Authority, Berea College, and the communities around Tuskegee and Talladega colleges, among many. ${ }^{21}$

This side of Holt - a factual, practical, "modern" side-continued to influence his work in the 1930s. He held hearings among Chicago's unemployed to gauge the dimensions of their suffering; and in 1933, during an upheaval in Iowa and adjacent states that fueled the farmers' "holiday" movement and the radical National Farmers' Union, his investigations enabled him to assess the likelihood of a farmers' strike with noteworthy accuracy. ${ }^{22}$ From these efforts he often was able to draw useful and specific recommendations.

There was another side, however, and Holt never overcame the bifurcation in his analysis of the rural crisis. This other side was a belief in the moral superiority of simple rural and village societies over commercial and industrial cities. Though for over two decades he made his home in Boston and Chicago and threw himself into urban causes, he was never fully comfortable in the milieu of the city. In the words of McGiffert, "He tended to interpret his urban studies drastically.... In fact, he gave his students the impression that he hated the city." 23

Part of the explanation of this urbanite's antiurbanism lies in his romantic memories of childhood: like many urban intellectuals of his generation, he had a heavy emotional investment in a simpler America. But part of the explanation also lies in the reinforcement that his views received from contemporary sociological thought, especially the school of urban sociology that flourished in Chicago under the leadership of Robert E. Park. A former newspaperman who studied at Michigan, Harvard, and Berlin before becoming a professor in the University of Chicago, Park believed that the city was not only a physical environment; it was, more importantly, a state of mind. Attitudes, forms of communication, customs, and bonds of social control that had kept freedom and order in balance in the small community were weakened in the city. In particular, he concluded that face-to-face

21. McGiffert, No Ivory Tower, p. 193; Arthur E. Holt, "Hiking Through the Milk Shed," Milk Market Reporter and Cream Shipper 8 (April 1929): 1, 9, 15; Samuel C. Kincheloe, "Social Explorer," CTS Register 32 (March 1942): 13-14.

22. Arthur E. Holt, "On the Trail of the Iowa Protesters," Christian Century 50 (17 May 1933): 651-653; Shover, Cornbelt Rebellion, p. 128.

23. McGiffert, No Ivory Tower, p. 190. 
association and cooperation in primary groups suffered in the city by comparison with preindustrial societies. Much of his work was directed toward finding ways of appropriating the values of the small town for the modern city, about which he had "deep reservations and feelings of uneasiness." ${ }^{24}$ Holt was part of an intellectual milieu in which such analyses were common. Though his own views of urban life were more strident, he can be understood properly only in the context of prevailing sociological assumptions, not as an isolated or eccentric figure. ${ }^{25}$

Holt's vision of a just society was essentially decentralist: only the small community could maintain the intimacy of primary relationships, direct communications, minor class distinctions, identification of self-interest with the public interest, and widespread community participation. Though not much given to theological reflection or to working with biblical materials in his writings, he did attempt to ground his decentralism in a general interpretation of the Bible. First set forth in 1920, this interpretation was repeated in later publications without modification. In Holt's view, the Hebrew ideals of justice and freedom had originated with the family and nomadic clan but were thwarted after the time of David as kingship became hereditary and power was consolidated in the cities taken over from the Amorites and Canaanites. The crucial juncture in Hebrew history occurred when, under Solomon and his successors, power passed from the villages, which had a democratic ethos, to the urban centers, whose values were those of "traders and traffickers." The growth of luxury and aristocracy and the city-dwellers' oppression of shepherds and peasants produced under Reheboam "lack of faith and disloyalty on the part of the people, and social anarchy was the result." Speaking for the hill country against the cities, the prophets reasserted the old values and decried the folly of "trying to build the nation at the top at the expense of those at the bottom." ${ }^{26}$ The exploitation of rural people by urban "traders and traffickers" served Holt as the archetype for urban-rural relations throughout subsequent history. Just as "the sin of one-sided development" had caused social anarchy in Hebrew history, so the

24. White and White, The Intellectual Versus the City, pp. 160-170. See also Quandt, From the Small Town to the Great Community, pp. 69-70, 150-154.

25. Holt used current work in urban sociology in the "Re-Thinking Chicago" movement, which originated under his leadership in 1931 and finally died out in 1937. Designed to awaken the city to its "lack of a 'soul" "and provide a "new philosophy and statesmanship," the movement relied on study groups and conferences. Reading lists included Robert E. Park and Ernest W. Burgess, The City (1925); Nels Anderson, The Hobo (1923); Ruth Cavan, Suicide (1928); Paul G. Cressy, The Taxi Dance Hall (1932); Clifford R. Shaw, Delinquency Areas (1929); idem, The Jack Roller (1930); Frederic M. Thrasher, The Gang (1927); and Harvey M. Zorbaugh, The Gold Coast and the Slum (1929). "Sociological Studies of Chicago," 2 pp. mimeographed, Holt Papers; Shirley E. Greene, "Re-Thinking Chicago: An Experiment in Christian Community Building" (M.A. thesis, University of Chicago Divinity School, 1935).

26. Arthur E. Holt, The Bible as a Community Book (New York, 1920), pp. 28-67, passim. 
Roman Empire had declined because "life's advantages were congested in the great central cities," the First World War had resulted from a clash between urban-based "merchant-manufacture-money lending alliance[s]," and the Bolsheviks had succeeded in Russia because they had "only to capture two great centers." 27

Holt could not ignore the positive urban imagery in the Bible. Though first seeing the city as a curse, the prophets recognized the irreversibility of the new political and economic conditions. Rather than trying to restore a tribal society, they made a major shift in the history of Hebrew idealism by envisioning the ideal society as a city of God. Their ideals finally were universalized by Jesus, "who would gather up in himself the fruits of the Hebrew community experience and lay the foundation for a social order founded on justice." 28

The difficulty was that, whereas the values of the Hebrew and Christian traditions and the decentralized democracy that he cherished and absolutized had specific association with actual historical communities, the positive images of urban life were futuristic. Holt's ideal city, a "serving city," would see itself "in all its functions-trading, manufacturing, money lending, and professional services-as the servant of the national process, and, instead of want[ing] to grab power ... would be glad to distribute power ... to the villages, the hamlets, and the towns." But when Holt assembled materials on the City of God for conference use in the 1930s, though he could draw together literary excerpts from prophets, seers, and utopians, he found no actual cities to celebrate. ${ }^{29}$ In fact, inspirational as it might be, the ideal also functioned negatively as a standard of judgment for urban societies.

Holt could only condemn the city as he found it. Motivated largely by the quest for profit, the dominant economic groups monopolized power for themselves. With Chicago in mind, he frequently described the city as a "tangled mass of old world loyalties" and a "towering pyramid of vocations" which had perverted service functions to self-aggrandizement. Though he faulted small towns for forgetting their service role, he asserted that they still provided a richer and more interesting life than cities, in which standardization and depersonalization prevailed. "If people ever discover what true community life is," he wrote, "they are going to desert the big city like rats from a sinking ship. It may be the place where they will go to work but it will not be the place where they will go to live." Urban churches, he insisted, must

27. Arthur E. Holt, "Wanted-A Distributed America," Kiwanis Magazine 11 (October 1926): 558-559, 592; and idem, "Cities and Revolution," Christian World 84 (8 April 1933): 5-6.

28. Holt, The Bible as a Community Book, pp. 49, 63.

29. Holt, "Cities and Revolution," p. 6. "Readings on the City of God," which was prepared for "Re-Thinking Chicago" and other meetings, contained sections on "The City of God as Seen by the Hebrews," "St. Augustine's City of God," "Humanistic Utopias," and other categories of literary excerpts. 
accept "a legitimate spiritual controversy with the present urban way of living." Such problems as gambling, crime, prostitution, and divorce were only "symptoms of a deeper malady": the city was "the place of depersonalized anonymous living." "Our problem," he concluded, "is not the problem of an out-of-date church in an up-to-date city. It is the problem of a personal way of life against a way of life which is built upon impersonal contacts." This problem was also afflicting India, the Soviet Union, and European colonies. $^{30}$

It was in the context of this dichotomized view of urban and rural values that Holt addressed the desperate situation in agriculture. The realism derived from his personal experience in the West and Midwest and from his penchant for investigation enabled him to identify specific agrarian problems and to evaluate and advocate various remedies. Fundamental to this realism was his understanding that power had flowed from rural areas to cities and that a better distribution of power, especially economic power, was needed. There could not be a "richer national fellowship" "until to a certain extent you have equals." ${ }^{31}$ Working with his students, he outlined in 1931 a comprehensive plan for agriculture, which included: (1) development of a national land policy that would preserve the family farm by scientific classification of land as a basis for fairer taxation, for relating agricultural production to future national needs, and for removal of submarginal lands from cultivation; (2) reforms in state and local tax systems to shift the burden from real estate to income, sales, and luxury taxes and to change the basis for real estate taxes from sales value to income value; (3) currency and price stabilization to end the historic pattern of farmers being victimized by cycles of inflation and deflation; and (4) adjustment of the tariff structure to give farmers "just, valuable, and adequate protection" while simultaneously lowering rates in order to increase foreign sales. This platform also called for reducing distribution costs, encouraging cooperatives, providing churches, libraries, schools, and recreational facilities, and upgrading rural housing. His approach was comprehensive, including both the economic and social needs of farmers; and he frankly endorsed national agricultural planning, "scientific" price setting, and governmental aid to cooperatives for collective

30. Arthur E. Holt, "Our Common Perversion," Christian Century 52 (26 June 1935): 850-852; idem, "Small Town America," Christian Advocate 102 (6 January 1927): 8-10; idem, "Values in Town and Village Life," ibid. 102 (13 January 1927): 42-43; idem, "Wanted-A Distributed America," p. 592; idem, "Next Great Step for the Church in the City," Christian Century 45 (26 July 1928): 927-929; idem, "Religion and City Tensions," ibid. 46 (24 July 1929): 938-940; idem, "This City-Controlled World," CTS Register 21 (March 1931): 6-10; idem, "Bigger and Better Peasant Wars!" Christian Century 51 (6 June 1934): 759-760; idem, "Justice for the Revolutionary Farmer!" ibid. 54 (8 December 1937): 1522-1524.

31. Arthur E. Holt, "Let Power Return to the Villages," Congregationalist 110 (8 January 1925): 41-42. 
purchasing of machinery. ${ }^{32}$ He earlier had offered incisive criticism of the McNary-Haugen plan, promoted in the late 1920s by the American Farm Bureau Federation and enacted twice by Congress only to be vetoed by Presidents Coolidge and Hoover. Though he preferred it to other proposals bandied about in those years, he recognized that, by dumping surpluses abroad in order to drive up domestic prices, it would not solve the problem of overproduction. ${ }^{33}$

The deepening farm crisis in the early 1930s evoked Holt's most bitter indictments of urban insensitivity to rural distress, and outbursts of midwestern agrarian radicalism brought forth expressions of sympathy that sounded quite militant. At every point of contact, urbanites had the advantage over ruralites: urban consumers demanded cheap food, regardless of the effect on rural living standards; urban creditors sanctimoniously upheld the inviolability of debts; well-organized manufacturers and labor unions resisted farmers' attempts to bargain collectively; and city-dominated legislatures stacked tax systems against rural landowners. The urban "trader class" carried a "bag of tricks" to maintain its privileges and yet mouthed the shibboleths of rugged individualism. ${ }^{34}$ Such comments displayed keen insight into the power relationships that kept rural Americans disadvantaged.

Urban liberals also received his censure. While "rugged individualists" opposed governmental action, except to help themselves, and "urban moralists" upheld the "debt-paying obligation," liberals "work[ed] for higher standards for urban labor, and $\mathrm{cr}$ [ied] for cheap food at the expense of the farmer." "It just isn't intellectually respectable to be interested in agriculture on most university campuses," Holt lamented. There were many conferences on race relations, world peace, and labor-management issues, but "not one word about the welfare of the man who does the basic work in all this country!" 35

32. Arthur E. Holt, "The Case for Rural Democracy," October 1931, Holt Papers; idem, "A Platform for Rural Democracy," CTS Register 21 (November 1931): 22-23.

33. Arthur E. Holt, "What the Farmer Really Needs," Christian Century 45 (15 November 1928): 1393-1395.

34. Arthur E. Holt, "Social Justice for the Farmer," CTS Register 23 (January 1933): 7-9; idem, "Social Justice between Farmer and City-Dweller," Federal Council Bulletin 17 (November-December 1934): 12-13; idem, "The Tricks of the Trader Class," Christian Century 49 (31 August 1932): 1051-1052; idem, "Challenged by the Trader-Controlled World," Cooperative Marketing Journal 6 (September-October 1932): 157-160; idem, "Is Debt Paying Moral?" University of Chicago Magazine 25 (December 1932): 61-63. See also idem, "This City-Controlled World," CTS Register 21 (March 1931): 6-10; idem, "More Hell and Less Hogs," Rural America 9 (December 1931): 3-5; idem, "The Beginning of a New Epoch," Journal of the National Education Association 21 (March 1932): 77-78.

35. Arthur E. Holt, "Urban People Want Cheap Food," Christian Century 49 (22 June 1932): 802-803; idem, "Urban Liberals and Agriculture," Rural America 12 (October 1934): 6-7. See also idem, "Urban Consumers and the Martyr Role," Christian Century 50 (13 December 1933): 1577-1578. 
Holt's politically oriented analysis extended to the agricultural colleges and farm organizations themselves. Visiting Iowa on his "Spring Hike" in 1933, not only did he find small town pastors "sit[ting] on top of a local volcano and preach[ing] sermons about international relationships," but he also found the American Farm Bureau Federation/extension agent/landgrant college axis looking out primarily for the interests of large commercial farmers. Sympathetic to the use of strikes and to demands for "cost of production plus" prices, he urged churches to hold hearings where militant farmers might air their views and suggested that dramatic tactics might be necessary for the radical organizations to advance their cause. ${ }^{36}$

For all his rhetoric, however, Holt believed in education rather than power as the principal lever of social change. Though he wrote of restoring power to the villages and farms and supported farmers' organizations, he was never comfortable with interest-group action. Wishing to change attitudes as the means to changing economic relationships, he saw direct action only as a means of persuasion. His preferred techniques were public hearings, study groups, and publications. In this reliance on exchanges of information and opinion to achieve social justice, he was reflecting a motif of the liberal Social Gospel. Nothing in his extant writings reveals reflection on the tactics of education and persuasion in the light of the critique of the Social Gospel formulated by Reinhold Niebuhr. He would seek justice for agriculture just as he would awaken Chicago to its need for a "soul," with idealistic literature, hearings, conferences, and, now and again, support of a particular reform. ${ }^{37}$ These were not only the methods of liberal Protestantism, they were also methods that accorded well with his understanding of local communities in America's past-communities in which firsthand acquaintance engendered mutual sympathy, idealism, and social well-being.

Not surprisingly, Holt approved the New Deal's programs for rural America, but only reticently. He personally liked Henry Wallace, so he applauded his appointment as secretary of agriculture and corresponded with

36. Arthur E. Holt, "Social Idealism in the Middle West," n.d., Holt Papers; idem, "On the Trail of the Iowa Protesters," 651-653; idem, "Communication: An Appeal to the Churches," Christian Century 50 (26 April 1933): 552-553. For Holt's own use of hearings, see "The Load on the Farmer's Back" (editorial), Christian Century 49 (15 June 1932): 760-762. On his sympathy for militants, see idem, "Silent Excommunication of the Poor," Christian Century 50 (15 November 1933): 1438-1439.

37. "Why A League for Justice to Agriculture," 4 pp. typescript, n.d., Holt Papers, delineates such methods. Arthur E. Holt, "Selling Agriculture to the City," Christian Century 53 (3 June 1936): 798-800, similarly stresses changing attitudes. Even Holt's justification of radicals in the Farmers' Union rested on his impression that, though they "sometimes have to take rather vigorous political action," "as they would interpret their own movement to themselves, it is a very idealistic group" (Holt to Gordon A. Riegler, 3 November 1934, Holt Papers). One of his enthusiasms in the "Re-Thinking Chicago" movement was the city manager plan, which, with its twin motifs of efficiency and nonpartisanship, promised to take the politics out of politics (Bulletin of the Chicago City Manager Committee 1 [June 1935]: 4; and H. Barry McCormick to "Dear Fellow Member," Chicago City Manager Committee, 13 January 1937, Holt Papers). 
him on occasion. He acknowledged that industry and labor practiced the economics of scarcity to maintain profits and wages but reluctantly approved the crop reduction mechanisms in the New Deal's farm program. He stoutly defended the Tennessee Valley Authority, seeing it not as a socialist venture but as a means to revitalize individualism by tackling the problems of the nation's most depressed region "community end first." He faulted the administration for not aiding farmers in Chicago's "milk shed" when agreements worked out earlier with milk companies and teamsters broke down. He wished that New Deal resettlement programs experimented more with communal ownership. And when the Supreme Court invalidated the Agricultural Adjustment Act in 1936, he chided the administration for rationalizing its new program as soil conservation, rather than attacking the court's narrow constitutionalism head-on. ${ }^{38}$

However, the New Deal did not restore the way of life that Holt desired, nor could it. Total farm income rose, federal agencies refinanced debts, much of rural America was electrified, and there were experiments with model communities, resettlement, and soil conservation. At the same time, large farmers received the lion's share of the cash benefits, many thousands of the poor were shuffled off the land, and the inexorable processes of economic concentration and migration to cities continued. Holt had hoped for "a new provincialism which will make the farmer's community significant," but the significance of that community in the future could not have been what he had had in mind. ${ }^{39}$

Holt's writings in his last few years appealed wistfully for a return to the face-to-face relationships of small communities. This appeal often was cast against the threat of totalitarianism. In two lecture series-This Nation Under God, prepared for the Rauschenbusch lectures at the ColgateRochester Divinity School in 1938, and Christian Roots of Democracy in America-and in The Fate of the Family in the Modern World, Holt celebrated the values of family and village as central to Christianity and democracy. Unless "little fellowships of the holy imagination which keep alive in men sensitivity to moral issues" could be preserved, democracy would "perish of the totalitarian plague which is spreading over the world." The crying need was for "new communities of responsible living." ${ }^{40}$ In this mood,

38. Holt to Wallace, 25 February 1933, Holt Papers; Holt, "Bigger and Better Peasant Wars!" pp. 759-760; idem, "Selling Agriculture to the City," pp. 798-800; idem, "Social Engineering in the Tennessee Valley," Advance 126 (19 April 1934): 54-55; idem, "The Government Is in Business," ibid. (26 April 1934): 69-70; idem, "Back of the Chicago Milk Strike," Christian Century 51 (24 January 1934): 121-124; idem, "The Future of Homestead Democracy," Christian Century 52 (29 May 1935): 723-724; idem, “America's Real Farm Issue," Christian Century 53 (19 February 1936): 290-291.

39. Holt, "Let Power Return to the Villages," pp. 41-42.

40. Arthur E. Holt, The Fate of the Family in the Modern World (Chicago, 1936); idem, This Nation Under God (Chicago, 1939), pp. 3, 83-84; idem, Christian Roots of Democracy in America (New York, 1941), p. xv, chaps. 5, 8. See also idem, "Why Cooperatives?" Farmers' Elevator Guide 36 (January 1941): 12. 
he found cause to question the growth of governmental involvement in people's lives that had occurred under the New Deal. In a speech at the Conference of Southern Mountain Workers in Knoxville, Tennessee, in 1940, he praised the revitalization of an Appalachian community. He went on to enumerate things the state does well and those it does not do well and cautioned churches and other private institutions not to yield too much to governmental programs. ${ }^{41}$ In this same vein, he became enamored of the ideas of the Danish-born Hjalmar Rutzebeck, who propounded a decentralist and antistatist philosophy of self-help and "reciprocal economy" (production for use) as alternatives to public relief. ${ }^{42}$

The supremacy of the romantic "search for new communities of responsible living" over tough grappling with economic and political realities finally carried Holt into leadership of a project that engaged the last few years of his life. This was an effort to create a "Christian thought center for a new America." The Merom Institute opened in August 1936 on the site of the defunct Union Christian College in Merom, Indiana, with support from the Congregational-Christian conferences of Illinois and Indiana, the Congregational Board of Home Missions and Council for Social Action (which Holt chaired), Chicago Theological Seminary, and the local community. In this community near Terre Haute Holt wished to conserve rural values, "vitalize and socialize" religion, provide reasons for people to stay in rural areas, work for "a distributed rather than a centralized America," and foster self-help. ${ }^{43}$

Seminary students received academic credit for field work around Merom, and Holt enlisted former students in the project as well. He poured substantial sums of his own money into the multifaceted enterprise, which included an extension service for rural churches, ventures in music, drama, and rural crafts, a library on rural economics and sociology, and a community

41. Arthur E. Holt, "The Church and the Welfare State," Mountain Life and Work 16 (Spring 1940): 1-3, 26. See also idem, "This is the Church's Job!" Christian Century 58 (20 August 1941): 1032, for his opposition to federalization of Civilian Public Service camps for conscientious objectors. Holt also became involved in the America First movement, supporting programs of the Hyde Park chapter, defending Senator Gerald Nye and Charles Lindbergh against criticism, and taking a critical view of the Lend Lease bill. Although he had other reasons, including the belief that intervention in the First World War had been a mistake, there is a striking compatability between his ruralist ideology and isolationism (Henry Nelson Wieman and Arthur E. Holt, "Keep Our Country Out of This War!" Christian Century 56 [27 September 1939]: 1162-1164; Holt to McGiffert, 30 January 1941; Fred L. Adair to Holt, 23 May 1941; Holt to Henry A. Atkinson, 31 October 1941; and Holt to Charles F. Boss, 6 February 1941, Holt Papers).

42. Arthur E. Holt, review of Common Sense in Idealism, by Hjalmar Rutzebeck, Christian Century 56 (4 January 1939): 23; Holt to Benson Y. Landis, 15 November 1939, Holt Papers;- - "Correspondence and Miscellaneous Papers: 'Relief from Relief' Meeting11/9/39-Self Help Groups," Holt Papers.

43. Paul A. Gettinger to author, 3 December 1980; Greene to author, 19 December 1980; Albert W. Palmer to Holt, 31 January 1936, Holt Papers; Arthur E. Holt, "The Neglected Factor in American Education," 30 August 1936, Holt Papers; idem, "The Merom Idea," CTS Register 31 (March 1941): 6-8. 
laundry. Holt thought that other similar projects might come into being, and he tried to interest other denominations in starting a rural seminary. Facing retirement in 1942, he anticipated moving to Merom. Though he died in his office before that could occur, as a final symbol his ashes were buried on the Merom grounds. ${ }^{44}$

Though the Merom facilities are still used for camps, conferences, and other programs, and although Holt's ideas remain strong there, the institute did not become a "Christian thought center for a new America." For in spite of his realistic social research and the concreteness of much of his thought, it was not a new America that Holt sought but rather the restoration of an older America that was rapidly disappearing - if it had ever existed.

Was Holt typical of urban liberal Protestantism in his day? Might his moralistic comparisons of urban and rural life, the incongruity between his hard-headed economic and political appraisals and his idealization of small communities, and his inability to identify an adequate restorationist program be attributed to the larger movements of which he was a part? Although much remains to be learned about the ideas of other rural life spokespersons and the programs of the principal rural life organizations, this much can be said: Holt was widely respected in a wide range of religious and secular circles, and he was strategically placed to disseminate his views. In the two decades when he was presenting his views to the public, similar and equally nostalgic evocations of a decentralized America were current, ranging from those of the "southern agrarians" at Vanderbilt to the northern subsistence homesteading projects of New York's Ralph Borsodi. If not everyone agreed with Holt, at least he represented a significant strand in the fabric of values and assumptions about the meaning of the rural experience which Americans brought with them into times of revolutionary change.

44. Shirley E. Greene, "The Merom Idea At Work," CTS Register 31 (March 1941): 8-11; "Minutes of a Meeting of the Faculty of the Chicago Theological Seminary," 4 November 1938, Holt Papers; Basinger, "Holt," p. 89; Holt to E. G. Kaufman, Rufus Bowman, and M. R. Ziegler, 18 November 1940, and Holt to Frank J. Scribner, 18 November 1941, Holt Papers. 